\title{
With a Little Help From our Friends: "Global" Incentives and "Local" Challenges to Feminist Politics in Brazil
}

\section{Cecilia M.B. Sardenberg}

\section{Introduction}

What are the major challenges facing feminists working to achieve gender justice in the context of development today? How are we to go about facing them? These were two of the major questions addressed by the 'Gender Myths and Feminist Fables' workshop participants, but to which no single solution was to be found. My own reactions are best conveyed by outlining current circumstances in Brazil. These reflect my close involvement in recent developments which, I believe, should foster the forging of a more equitable Brazilian society.

\section{Defining feminist futures: Brazil's "Year of Women"}

As part of a cheering assembly of more than 600 women delegates to the First Women's Conference of the State of Bahia, I could not help but feel optimistic for the future of women's struggles in Brazil. Indeed, after three long days of engaged presentations, intense discussions, and (not always friendly) negotiations on the sidelines, we were finally able to draw up and approve a rather progressive programme towards building gender equity in Brazil, to be presented to our state and federal governments.

Coordinated by the State Council for the Defense of Women's Rights (CDDM) and sponsored by government agencies, this Conference was held in Salvador (the state capital) at the beginning of June 2004, following 22 municipal and regional conferences that took place throughout the state in the previous months. In each of these conferences, the delegates were called upon to discuss the shortcomings of public policy for women in the face of "Brazilian social reality", and to propose new policies on issues relating to unemployment, income generation, domestic violence, health programmes, and so forth.

This process was launched by the Lula government which established 2004 as Ano da Mulher (Women's Year), through federal law. As part of the events for this year, the Special Bureau of Policies for Women (SPM - Secretaria Especial de Políticas para Mulheres), also created by the Lula government with a cabinet status, is organising the First National Conference on Policies for Women (I Conferência Nacional de Politicas para Mulheres), to take place 15-18 July 2004 in Brasília, the national capital. More than 2,000 women delegates elected by their peers in the state conferences, held all over the country, are expected to assemble in Brasília myself included. The stated purpose of this nationwide process is to establish a dialogue between civil society and government - from the municipal through the federal levels - for the formulation of public policies towards the eradication of gender inequalities in Brazil.

Obviously, since the initiative comes from the federal government and, as such, it is identified with 'PT', Lula's Workers Party, support for the municipal, regional, and state conferences - and, consequently, commitment towards the implementation of the policies proposed - has depended upon local political allegiances. In the Salvador Conference, for instance, the Municipal Council for Women's Rights had nearly no support from local state agencies. Similar problems were faced by the organisers of the Conference for the State of São Paulo, the first in the country in terms of population, and which is presently governed by an opposition party. 
In any event, patriarchal relations are still very strong in the Brazilian hinterlands, particularly in the Northeast region, which means that, despite the "capillarity" activated in the conference process, many delegates are not only far from being "activists", but also of even supporting established demands of the women's movements. Some communities, in fact, even sent men as delegates to the women's conference - one community in Bahia sending a Catholic priest who was heard saying that he had come to 'crush any proposal favouring of the decriminalisation of abortion'. (Too bad for him, the proposal was approved!) Another delegation from the southernmost tip of the state attempted to appoint a man as national delegate, but was forced to withdraw his name after the loud majority of participants in the State Conference voiced their protest.

Of course, one cannot expect that the forthcoming National Conference will result in the formulation of a document as progressive as the Feminist Political Programme (Plataforma Politica Feminista), elaborated for the 2002 national elections. Drawn up through a similar process of state conferences launched by the Articulation of Brazilian Women (AMB - Articulação de Mulheres Brasileiras), a network of women's forums and feminist groups throughout the country, and approved in a national conference also held in Brasília, the Feminist Political Programme advanced women's demands far beyond gender-specific issues. Indeed, we dared to voice our position regarding the future of the country at large.

Regardless of the present shortcomings, however, this is certainly a very special moment for Brazilian feminists: we believe we can make a difference at the National Conference and I am sure we will. However, in so doing, we must recognise that we have not been alone in our endeavour: global feminisms have helped us in the way of granting legitimacy to our local struggles.

\section{Global feminisms and local struggles}

Indeed, although much has been said lately about the shortcomings of the "globalisation of feminism" and of the subversion of feminist politics by developmental agendas, ${ }^{1}$ it would be unfair to deny their important contribution to the advancement of local struggles. In the case of Brazil, at least, it is a well-established fact that the designation of 1975 as 'International Women's Year' by the United Nations, marked by the International Women's Conference held in Mexico City that same year, had a determining role in the launching of the contemporary Brazilian feminist movement. Until then, the military dictatorial regime that had been established with the 1964 coup had succeeded in keeping women's struggles off the streets by violently repressing any type of public manifestation (Sardenberg and Costa 1994). The UN initiative not only granted a new status to the cause of women in Brazil (Pinto 2003) but it also opened the way for local expressions in that direction - such as the UN-sponsored conference held in Rio de Janeiro, which resulted in the creation of the Centre for the Development of the Brazilian Woman (Centro de Desenvolvimento da Mulher Brasileira). It was also in 1975, with UN legitimacy, that feminist meetings began to be held during the annual conferences of the Brazilian Society for the Advancement of Science (SBPC), a practice which lasted for the following ten years and marked feminist incursions into the academic world (Costa and Sardenberg 1994; Sardenberg and Costa 1994; Pinto 2003). ${ }^{2}$

During the 1980s, as other social movements, so too women's struggles in Brazil gained momentum, flourishing as the country embarked on the road towards re-democratisation (Alvarez 1990). Nevertheless, the UN International Women Conferences, such as the 1985 Nairobi Conference, the 1995 Beijing Conference, and the subsequent Beijing +5 and the upcoming Beijing +10 Conference, to be held in 2005, have continued to provide needed global support to local feminist demands. It is worth pointing out, for instance, that AMB, the 'Articulation of Brazilian Women' was created in 1995 precisely to organise Brazilian women's participation in the Beijing Conference. Indeed, speaking of the impact of these conferences on women's movements in Brazil, Maria Aparecida 'Shuma' Shumaher, one of the coordinators of AMB, has observed that:

This mobilisation provoked and constituted (women's) Forums/Articulations in 25 Brazilian states, and the promotion of nearly one hundred events (state meetings, seminars, research projects, etc.), involving more than 800 organisations. In the history of Brazilian women's movements, I do not know of any other international event that has counted with such 
an intense mobilisation in the country. In some Brazilian counties, the Beijing event stimulated the creation of new spaces for debate. For the first time women's movements elaborated 22 documents/diagnostics which showed the complex nature of inequality among women in the country, giving us the opportunity to evaluate the degree of organisation of the movement in each one of these states, assess regional priorities, and propose the design of policies to be implemented (in Pinto 2003: 114-15, my translation from the original in Portuguese).

However, it should be stressed that such an impact does not mean necessarily that women's movements in Brazil have been led by the whims of international development agendas. To the contrary, we have been noted not only for the originality and exuberance of our feminist expressions, but also for their vitality and capacity for constant renewal even in adverse conditions (Alvarez 1990; Alvarez 1998). More importantly, in most cases, we have been able to use these agendas to the benefit of our struggles towards a more equitable society - which, at least in theory, is the major objective of these agendas after all.

Of course, far from claiming any victory ahead of time, it must be kept in mind that many are the challenges placed to feminist engagement in the discussions to come.

\section{Re-democratisation in an era of globalisation}

Current debates on these challenges have called attention to two distinct, even contradictory, processes that have profound implications for the formulation of policies regarding women's issues. On one hand, in the last three decades, we have witnessed the gradual re-democratisation of our political institutions, a process marked by the emergence of new actors in the national arena including feminists - that have made events such as the forthcoming National Conference a possibility. On the other hand, we have suffered the effects of a perverse combination of the processes of globalisation, production restructuring, and the large-scale advancement of neo-liberalism, which have made labour relations even more fragile and resulted in the widespread impoverishing of the population. In particular, the implementation of fiscal adjustment policies demanded by the
International Monetary Fund, with the consequent cuts in social programmes, have rendered the life of the Brazilian poor labouring classes even more difficult, if not downright painful.

As such, despite the important advancements made towards the re-establishment of political and citizenship rights which have culminated with Lula's swearing-in as President, Brazilian society is still profoundly marked by social inequalities, particularly those resulting from the intersection of gender, class, race, age and other equally widespread social determinants.

\section{What progress for women?}

Even if inequalities between women and men still persist, they have tended to narrow within given social groups, whereas inequalities among women - especially between black and white women - have instead widened considerably. For example, data from the 2000 population census brought good news with respect to women and education. The data points out that women have supplanted men in all levels of schooling, and particularly at the university levels. However, this does not apply to all women in the same way. Whereas the proportion of white women who have completed secondary schooling has grown to 17.2 per cent, only 10.2 per cent of all black women have reached that same status. Similar differentials were found in terms of college education: 7.7 per cent among white women, and a mere 1.9 per cent for non-white females (IBGE 2003).

Women as a whole still earn lower average incomes than men, regardless of their colour/ethnic groups and independent of their level of schooling. As matter of fact, the distortions increase as we move up in terms of years of schooling. Nevertheless, white women, as a whole, earn more than black men, while black women earn, on average, half of the earnings of white women and a mere fourth of what white men receive. Besides, as a whole, black women tend to face the most precarious conditions of insertion in the labour market.

\section{The feminisation of poverty: no "feminist fable" in Brazil}

Another issue which should deserve special attention on the part of feminists is the noticeable increase of the proportion of women-headed households. In Bahia, this proportion rose from 20.0 per cent of the homes in 1991, to 27.1 per cent in 2000, corresponding to an increment of 
35.3 per cent (IBGE 2003). This rise was more pronounced in urban areas than rural ones. In the city of Salvador, for example, women-headed households, composed of 'women and their children', correspond to 37.5 per cent of all the homes (IBGE 2003; Berquó 2002).

These statistics gain significance as well from current debates on the "feminisation of poverty". In Brazil, at least, this is not necessarily a "feminist fable"; studies have revealed that households headed by women present greater vulnerability to poverty than other households, in that the female heads are more likely to be among the unemployed or working part-time, and pooling, on average, more reduced earnings (Lavinas 1996). Indeed, according to the 2000 census, nuclear family households headed by men earn, on average, $\$ 295,80$ reais (about $\mathrm{f60}$ ), while this average is reduced to $\$ 263,90$ reais (about $£ 52$ ) in the case of households headed by a woman living alone with her children. And the situation is considerably worse in the case of households headed by black women; these households earn, on average, 74 per cent less than households headed by white men (IBGE 2003; Berquó 2002).

Insofar as this situation is more crucial in the case of families headed by black women, poverty reduction policies in Brazil must take a gender and race approach. By the same token, poverty reduction and the fight against racism will be among the fundamental challenges posed to feminist activists in the upcoming National Conference. This will be especially so for those of us in the Bahia delegation, as we will be representing not only the state which

\section{Notes}

1. At the IDS workshop, my own paper was critical of the ways in which the appropriation of the category "gender" by international development agencies has contributed to the vulgarisation and neutralisation of the concept, in robbing it of its political character. See also Sardenberg, Costa and Passos (1999). concentrates the largest black population in Brazil, but also one of the poorest states in the country. For certain, feminists from Bahia will need to take a strong stand in favour of affirmative action policies on gender and race lines, as well as press for stronger and more inclusive social programmes geared at poor families, particularly those headed by women. In that regard, it must be stressed that existing programmes, including the new ones being implemented by the Lula government, such as the Bolsa Familia (Family Grant) still remain basically paternalist; they merely assist women. It will be up to us, feminist delegates, to ensure that new policy to come will actually empower women, such as to tend to our strategic interests.

\section{Futures possible}

Finally, I must confess that my optimism about the National Conference does not necessarily rely on faith in the federal government's commitment to women's issues. In point of fact, to this day, Lula has yet to answer our demands for the nomination of a feminist as head of the Special Bureau for Women's Policies; apparently, he has traded commitment to our cause for allegiance to party politics.

However, it must be recognised that the designation of 2004 as Ano da Mulher, as well as the calling for the First National Conference on Policies for Women, has already had a positive impact on the course of women's struggles in Brazil towards gender equality. Indeed, they have finally granted visibility and legitimacy to these struggles, so long claimed and deserved by feminism in Brazil.

2. Since 1985, Feminist Meetings have been held independently of the SBPC Annual Meetings. 


\section{References}

Alvarez, S.E., 1990, Engendering Democracy in Brazil: Women's Movements in Transition Politics, Princeton, New Jersey: Princeton University Press

Alvarez, S.E., 1998, 'Latin American Feminisms "Go Global": Trends of the 1990s and Challenges for the New Millennium', in S.E. Alvarez, E. Dagnino and A. Escobar (eds), Cultures of Politics/Politics of Cultures: Revisioning Latin American Social Movements, Boulder, Colorado: Westview Press

Berquó, E., 2002, 'Perfil demográfico das chefias femininas no Brasil', Gênero, Democracia e Sociedade Brasileira, August, Edn 1, Editora 34: 243-65

Costa, A.A.A. and Sardenberg, C.M.B., 1994, 'Teoria e praxis feministas nas ciências e na academia: os núcleos da mulher nas universidades brasileiras', Revista Estudos Feministas, Rio de
Janeiro: CIEC/ECO/UFRJ, Número Especial: Anais do Simpósio Internacional, 'Formação, Pesquisa e Edição Feministas nas Universidades': 387-400

IBGE, 2003, Sintese de Indicadores Sociais, Rio de Janeiro: Instituto Brasileiro de Geografia e Estatística (IBGE)

Lavinas, L., 1996, 'As mulheres no universo da pobreza: o caso brasileiro', Revista Estudos Feministas, Vol 4 No 2: 464-79

Pinto, C.R.J., 2003, Uma História do Feminismo no Brasil, São Paulo: Editora Fundação Perseu Abramo

Sardenberg, C.M.B. and Costa, A.A.A., 1994, 'Feminismos, Feministas e Movimentos Sociais', in M. Brandão and M. Clara Binghemer (eds), Mulher e Relaçıes de Gênero, São Paulo: Ed. Loyola Sardenberg, C.M.B., Costa, A.A.A. and Passos, E., 1999, 'Rural development in Brazil: are we practising feminism or gender?', Gender and Development, Vol 7 No 3: 28-38 